\title{
THE ROLE OF THE MILITARY \\ LOGISTIC SYSTEM IN SUPPORT \\ OF THE CIVIL CRISIS MANAGEMENT \\ OPERATIONS TO MITIGATE \\ THE EFFECTS OF NATURAL \\ DISASTERS AND TECHNICAL \\ FAILURES: THE CASE STUDY \\ OF POLISH MILITARY LOGISTICS
}

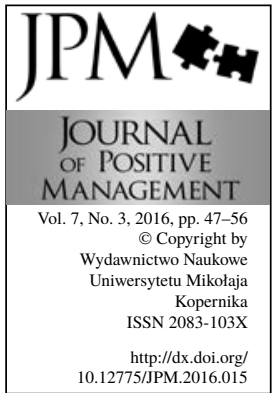

\author{
Andrzej Lis
}

Nicolaus Copernicus University in Torun,

The Faculty of Economic Sciences and Management, Toruń, Poland

e-mail: andrzejlis@econ.umk.pl

\begin{abstract}
Research purpose: The aim of the paper is to identify the scope of the engagement of the military logistic system in supporting civil crisis management operations and reducing the negative effects of natural disasters and technical failures.

Methodology/approach: The single case study methodology is applied to achieve the aim of the research. The case analysis focuses its attention on the logistic system of the Polish Armed Forces as the unit of the study. The following methods have been used to collect the data for the study: literature review, documentation analysis, analysis of the news published on the website of the Inspectorate for the Armed Forces Support and participatory observation.

Findings: The key areas of support provided by military logistics for the operations of civil crisis management encompass preparing the conditions for temporary stay of evacuated population and medical support. The lessons identified from the civil crisis management operations conducted between 2008 and 2015 confirm that the scope of real life support provided by the military logistic system is consistent with the priorities of crisis and humanitarian logistics which include supplies of drinkable water, food, clothes, electric power and logistic services.
\end{abstract}

Limitations/implications: The applied methodology of the single case study limits the possibility to generalize the findings. The analysis is deeply embedded into a given context i.e. civil crisis management operations supported by Polish military logistics between 2008 and 2015 .

Originality/value: So far, not enough research attention has been given to the issue of the military logistics engagement in supporting the civil crisis management to mitigate the negative effects of 
natural disasters and technical failures. Therefore, the study contributes to the efforts to fill the identified gap in knowledge.

Keywords: military logistics, crisis management, natural disaster relief operations

Paper type: Research paper

\section{Introduction}

Disasters include natural catastrophes and technical failures which endanger live and health of numerous population, property of high value and the large areas of the natural environment (The Act on the State of Natural Disaster, 2002). In order to effectively counteract such disasters and mitigate their negative effects all the services of the public administration are to combine their efforts and operate collectively (The Act on the State of Natural Disaster, 2002, article 3, paragraph 1, point 1). Therefore, supporting the civil crisis management to mitigate the negative effects of natural disasters and technical failures is listed among the missions assigned to the Polish Armed Forces (Kuśmierek, 2014; Lisowski, 2009).

According to the Polish legal regulations, crisis management encompasses the activities of public administration focused on ,,preventing crisis situations, preparing to take control over them by way of planned activities, responding in case of emergencies, removing their effects and reconstructing resources and critical infrastructure" (The Act on Crisis Management, 2007, article 2). This should be clearly distinguished from the term of crisis management used by NATO to denote "[t]he coordinated actions taken to defuse crises, prevent their escalation into an armed conflict and contain hostilities if they should result" (AAP-6, 2015, p. 2-C-17).

Among all the branches of armed forces, the mission to support the civil administration in mitigating the negative effects of natural disasters and technical failures is mainly the responsibility of engineering troops (Bębenek, 2014; Ciszewski, 2011). In NATO and some member states of the Alliance (e.g. in the United States), the elements of engineering capabilities are included into their logistic systems and they perform one of the functions of the operational logistics i.e. Infrastructure Engineering for Logistics in NATO (cf. NATO Logistics Handbook, 2012) and Engineering or General Engineering Support in the United States Armed Forces (cf. JP 4-0, 2013, p. II-10; ADP 4-0, 2012, pp. 1-2; ADRP 4-0, pp. 1.1-1.2). Nevertheless, in the Polish Armed Forces there are not any engineering elements within the functional structure of the military logistic system, which includes the following subsystems: management, supply, maintenance and recovery, movement and transportation, medical and military infrastructure (Jałowiec, 2013a; Jałowiec, 2013b; Lis and Jałowiec, 2015). 
Due to their crucial role and direct engagement in supporting civil crisis management, counteracting natural disasters and technical failures and mitigating their negative effects, engineering troops attract the majority of the research attention on the engagement of the Polish Armed Forces in this type of missions (e.g. Włudyka et al., 2010). In such a context, the engagement and the role of military logistics in the support of civil crisis management operations seem to be unexplored areas, which establishes the niche for further exploration. The aim of the paper is to identify the scope of the engagement of the military logistic system in supporting civil crisis management operations and reducing the negative effects of natural disasters and technical failures. In order to operationalise the aforementioned aim of the study, two following research problems have been set:

1) What is the potential scope of the engagement of the military logistic system in supporting civil crisis management operations and reducing the negative effects of natural disasters and technical failures?

2) What was the real engagement of the military logistic system in supporting civil crisis management operations and reducing the negative effects of natural disasters and technical failures?

3) The single case study methodology (Myers, 2010; Stake, 2010; Strumińska-Kutra and Koładkiewicz, 2010; Yin, 2010) is applied to achieve the aim of the study and solve the research problems. The case analysis focuses its attention on the logistic system of the Polish Armed Forces as the unit of the study. The following methods have been used to collect the data necessary for the analysis and ensure the appropriate level of triangulation: literature review, documentation analysis, analysis of the news published on the website of the Inspectorate for the Armed Forces Support and participatory observation. The literature review is based on purposeful selection of articles (narrative review) covering two areas: military logistics and the engagement of the armed forces in the support of civil crisis management operations. The review of national legal acts is to provide the foundations for the analysis of the potential scope of the engagement of the military logistic system in supporting civil crisis management operations and reducing the negative effects of natural disasters and technical failures. Both, the analysis of the news published on the website of the Inspectorate for the Armed Forces Support and participatory observation are used to identify the real engagement of the military logistic system in supporting civil crisis management operations and reducing the negative effects of natural disasters and technical failures. The analysis covers the news published between 01 January 2008 when the Inspectorate achieved its full operational capability and 30 June 2015. The participatory observation encompasses period between 2007 and 2011, when the author was working for the Inspectorate and was 
engaged in monitoring the use of military logistics forces in supporting civil crisis management operations and counteracting the negative effects of natural disasters and technical failures.

\section{Potential scope of military logistics engagement in support of civil crisis management}

The main mission of the Polish Armed Forces is to „safeguard the independence and territorial integrity of the State" and "to ensure the security and inviolability of its borders" (The Constitution of the Republic of Poland, 1997, article 26, paragraph 1). However, the legal regulations enable the Polish Armed Forces to engage in counteracting natural disasters and mitigating their effects, counterterrorism activities, search and rescue operations, mine and explosives clearing and the support of civil crisis management operations (The Act on National Defence Duties, 1967, article 3, paragraph 2).

According to the Act on Crisis Management "[i]f in a crisis situation the use of other capabilities and resources is impossible or may prove to be insufficient $[\ldots]$ the Minister of Defence, at the request of the voivode may provide him with subunits or units of the Armed Forces of the Republic of Poland [...] and assign them to carry out crisis management tasks" (The Act on Crisis Management, 2007, article 25, paragraph 1). Similar regulations are in place in the state of the natural disaster (The Act on the State of Natural Disaster, 2002, article 18, paragraph 1). However, the missions related to national defence and allied operations are the priorities for the Polish Armed Forces, and the act on crisis management confirms the primacy of these missions over the engagement in support of civil crisis management operations (The Act on Crisis Management, 2007, article 25, paragraph 9).

The missions accomplished by the Polish Armed Forces for the benefit of the national crisis management system are enumerated by the aforementioned act on crisis management (The Act on Crisis Management, 2007, article 25, paragraph 3). Their scope is very similar to the catalogue provided by the regulation on the engagement of the Polish Armed Forces in counteracting the effects of natural disasters (The Regulation of the Council of Ministers on the Use of Polish Armed Forces in Disaster Relief Operations, 2003, section 2, paragraph 1). In Table 1, among the missions of the Polish Armed Forces listed in the act on crisis management, there are identified those which may require the engagement of military logistics. Moreover, the components of the military logistic system most likely to be engaged in such operations are highlighted.

The analysis of the data collected in Table 1 shows that among 15 tasks assigned to the Polish Armed Forces to support civil crisis management operations and counteracting natural disasters and technical failures, the military logistic system may be engaged in 7 types of missions. There are two areas where the potential of military logistics may be particularly useful: 


\begin{tabular}{|c|c|c|c|}
\hline No. & Activity & $\begin{array}{l}\text { Engage- } \\
\text { ment of } \\
\text { military } \\
\text { logistics }\end{array}$ & $\begin{array}{l}\text { The subsystem } \\
\text { of the military } \\
\text { logistic system to } \\
\text { be engaged }\end{array}$ \\
\hline 1. & monitoring of threats & - & - \\
\hline 2. & $\begin{array}{l}\text { evaluation of the effects of events that occurred in the area } \\
\text { where threats exist }\end{array}$ & - & - \\
\hline 3. & search and rescue operations & - & - \\
\hline 4. & evacuation of affected population and property & $\mathrm{S}$ & $\begin{array}{l}\text { movement and } \\
\text { transportation }\end{array}$ \\
\hline 5. & $\begin{array}{l}\text { preparing the conditions for temporary stay of evacuated } \\
\text { people in the designated places }\end{array}$ & $\mathrm{P}$ & $\begin{array}{l}\text { infrastructure, } \\
\text { supply }\end{array}$ \\
\hline 6. & protection of property in the area where threats exist & - & - \\
\hline 7. & $\begin{array}{l}\text { isolation of the area where the threats exist or the place } \\
\text { where the rescue operation is carried out }\end{array}$ & - & - \\
\hline 8. & $\begin{array}{l}\text { protective, rescue and evacuation activities on threatened } \\
\text { buildings and historical buildings and monuments }\end{array}$ & $\mathrm{S}$ & infrastructure \\
\hline 9. & $\begin{array}{l}\text { activities requiring the use of specialist technical equ- } \\
\text { ipment or explosives from the resources of the Armed } \\
\text { Forces of the Republic of Poland }\end{array}$ & S & $\begin{array}{l}\text { maintenance and } \\
\text { recovery }\end{array}$ \\
\hline 10. & removal of dangerous materials and their neutralisation & - & - \\
\hline & chemical and biological decontamination & - & - \\
\hline 12. & radioactive decontamination & - & - \\
\hline 13. & repair and reconstruction of technical infrastructure & $\mathrm{S}$ & infrastructure \\
\hline 14. & clearing routes of transportation & $\mathrm{S}$ & $\begin{array}{l}\text { movement and } \\
\text { transportation }\end{array}$ \\
\hline 15. & medical support and hygiene and anti-epidemic measures & $\mathrm{P}$ & medical \\
\hline
\end{tabular}

The engagement (role) of the military logistic system: $\mathrm{P}$ - primary; $\mathrm{S}$ - secondary (supporting)

- preparing the conditions for temporary stay of evacuated people in the designated places;

- providing medical support and undertaking hygiene and anti-epidemic measures.

The former is mainly the responsibility of the military infrastructure potential. However, some elements of the supply subsystem may also contribute providing the evacuated population with food, tents, blankets, towels etc. As regards the latter, the military medical capability is to be engaged and the role of psychological support is worth emphasizing.

Besides direct engagement in civil crisis management operations, the military logistic system is responsible for providing logistic support to other components of the Polish Armed Forces taking part in such operations (e.g. engineering troops,

THE ROLE

Table 1.

The activities of the Polish Armed Forces in support of civil crisis management operations

Source: Own study based on: The Act on Crisis Management (2007, article 25, paragraph 3). 
NBC units, military police). Moreover, military aviation provides transportation services for rescue and humanitarian operations abroad e.g. operations after the earthquakes in Nepal (2015), Haiti (2010), Iran (2003), India (2001) and Turkey (1999) (Wróbel, 2015).

\section{Real-life military logistics engagement in support of civil crisis management}

The potential scope of the engagement of the Polish Armed Forces, including the military logistic system, in support of civil crisis management operations, in practice is determined by real needs and the capabilities of other public institutions and services (e.g. fire departments). In order to identify the real-life engagement of military logistics in civil crisis management operations, Table 2 presents the list of natural disasters and technical failures which required the use of military forces. The catalogue covers the period from 2008 to mid-2015 and distinguishes between the type of forces engaged i.e. engineering troops and military logistics. Whenever logistics was engaged, additional information concerning the scope of provided support is included.

In the period of time under analysis (from 01 January 2008 to 30 June 2015), the Inspectorate for Armed Forces Support provided its forces to 11 operations of civil crisis management. 10 of them were minor operations of a limited scope which required a low level of engagement of military potential and forces. There was 1 major operation engaging a wide scope of the support from the military i.e. summer flooding in May and June 2010 (cf. Lisowski, 2011). Among these 11 operations, the components of the military logistic system were engaged 5 times. The scope of the provided support encompassed deliveries of food, blankets, mattresses, cleaning supplies, containers and the use of specialised military equipment such as: heavy equipment transporters, military trucks and power generators. During the flooding of 2010 and wind storms of 2008, military psychologists provided assistance to the victims of these disasters.

\section{Conclusion}

The analysis shows that the scope of potential support provided by military logistics in the operations of civil crisis management encompasses first and foremost preparing the conditions for temporary stay of evacuated people and medical support. The components of the military logistic system may be also included into evacuation of affected population and property, protective, rescue and evacuation activities on threatened buildings and historical buildings and monuments, activities requiring the use of specialist technical equipment or explosives from the military resources, repair and reconstruction of technical infrastructure and clearing roads to be passable. 

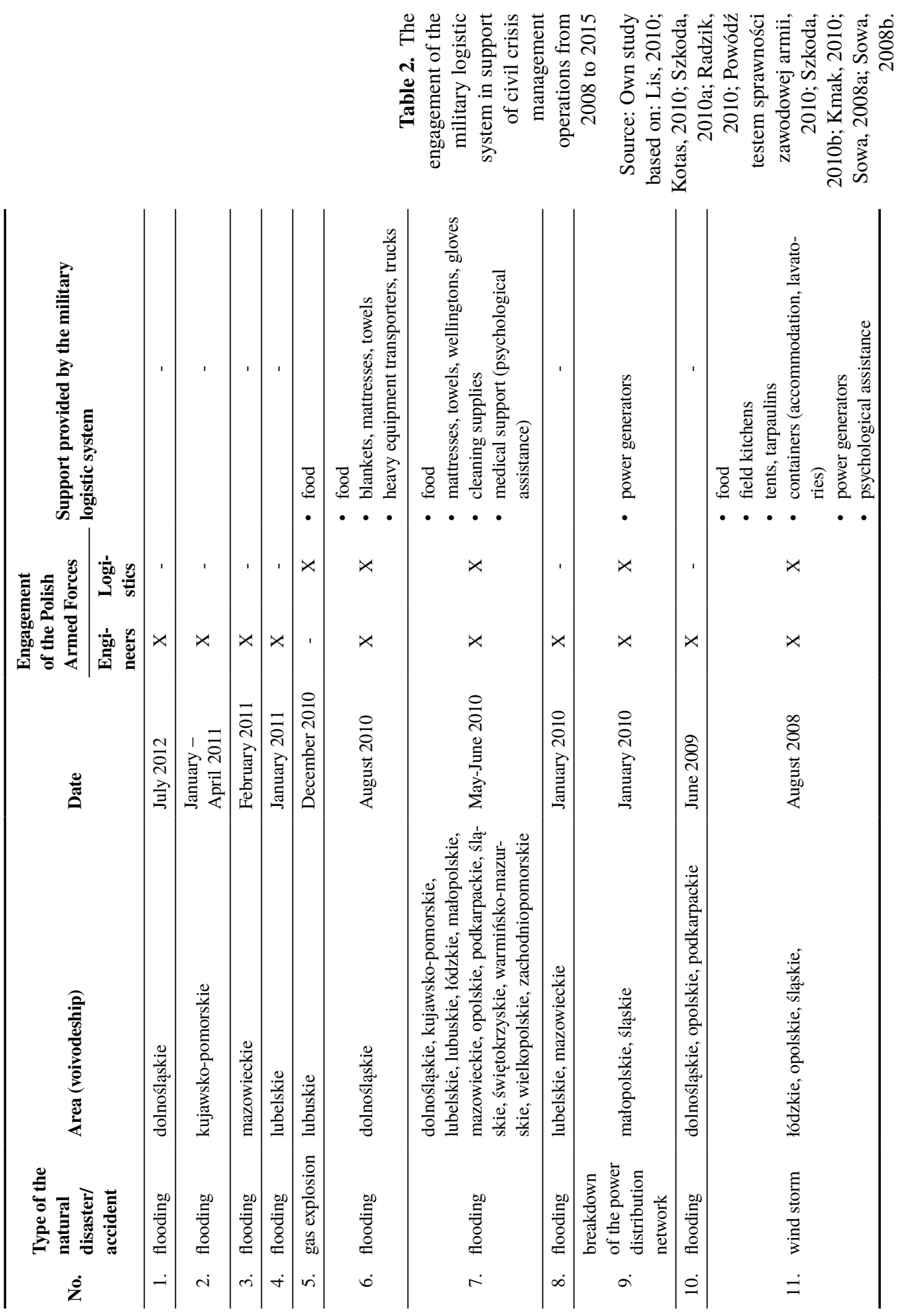
The lessons identified from the civil crisis management in 2008-2015 confirm that the scope of real life support provided by the military logistic system is consistent with the priorities of crisis and humanitarian logistics which include supplies of drinkable water, food, clothes, electric power and logistic services (cf. Nowak, 2009). Simultaneously, military logistics is responsible for providing necessary support for the benefit of other military components participating in civil crisis management operations, such as engineering troops or military police.

\section{References}

Bębenek, B. (2014), “Wyzwania inżynierii wojskowej”, Przegląd Sił Zbrojnych, No. 2, pp. $8-12$.

Ciszewski, T. (2011), "Udział Sił Zbrojnych Rzeczypospolitej w zapobieganiu oraz usuwaniu skutków zagrożeń niemilitarnych”, Zeszyty Naukowe WSOWL, No. 2, pp. 363-383.

Jałowiec, T. (2013a), Efektywność w wojskowym systemie logistycznym: Zarys problemu, Akademia Obrony Narodowej, Warszawa.

Jałowiec, T. (2013b), Wspótczesne koncepcje i metody zarzq̨dzania w logistyce wojskowej: Analiza, ocena i propozycje dla Sit Zbrojnych Rzeczypospolitej Polskiej, Akademia Obrony Narodowej, Warszawa.

Kmak, S. (2010), "Logistycy pomagają w walce z zimą", available at: http://www.iwspsz. wp.mil.pl/pl/72_823.html (accessed 13 July 2015).

Kotas, M. (2010), "Wojsko pomaga poszkodowanym w powodzi", available at: http:// www.iwspsz.wp.mil.pl/pl/72_984.html (accessed 13 July 2015).

Kuśmierek, Z. (2014), “Udział wojska w sytuacjach kryzysowych”, Zeszyty Naukowe Państwowej Wyższej Szkoły Zawodowej im. Witelona w Legnicy, No. 10 (1), pp. 15-22.

Lis, A. (2010), "Wojsko pomaga Zielonogórzanom", available at: http://www.iwspsz. wp.mil.pl/pl/72_1096.html (accessed 13 July 2015).

Lis, A., Jałowiec, T. (2015), "The Systems Approach to Transform the Capabilities of Military Logistics", Buletin Stiintific, Vol. 20, No. 2, pp. 151-161.

Lisowski, G. (2009), "Rola i zadania Sił Zbrojnych w zarządzaniu kryzysowym państwa, Przedsiębiorczość i Zarządzanie, Vol. 10 No. 6, pp. 69-86.

Lisowski, G. (2011), "Rola sił zbrojnych podczas powodzi", Przedsiębiorczość $i$ Zarządzanie, Vol. 12 No. 2, pp. 103-120.

Myers, M. D. (2010), “Case Study Research”, in: Frenz, M., Nielsen, K., Walters, G. (Eds.), Research Methods in Management, SAGE, London, pp. 227-248.

Nowak, E. (2009), "Logistyka i zarządzanie logistyczne w sytuacjach kryzysowych", Przedsiębiorczość i Zarządzanie, Vol. 10 No. 8, pp. 9-22.

Powódź testem sprawności zawodowej armii (2010), available at: http://www.iwspsz. wp.mil.pl/pl/72_958.html (accessed 13 July 2015).

Radzik, L. (2010), “Opolscy logistycy pomagają powodzianom”, available at: http://www. iwspsz.wp.mil.pl/pl/72_986.html (accessed 13 July 2015).

Sowa, A. (2008a), "Żołnierze pomagają poszkodowanym”, available at: http://www. iwspsz.wp.mil.pl/pl/52_249.html (accessed 12 July 2015). 
Sowa, A. (2008b), "Wojsko nadal pomaga poszkodowanym przez katastrofalne wichury", available at: http://www.iwspsz.wp.mil.pl/pl/52_256.html (accessed 12 July 2015).

Stake, R. E. (2010), “Jakościowe studium przypadku”, in: Denzin, N. K., Lincoln, Y. S. (Eds.), Metody badań jakościowych, Vol. 1, PWN, Warszawa, pp. 623-654.

Strumińska-Kutra, M., Koładkiewicz, I. (2012), “Studium przypadku”, in: Jemielniak, D. (Ed.), Badania jakościowe: Metody i narzędzia, Vol. 2, PWN, Warszawa, pp. 1-40.

Szkoda, A. (2010a), "Logistycy znów pomagają powodzianom”, available at: http://www. iwspsz.wp.mil.pl/pl/72_980.html (accessed 13 July 2015).

Szkoda, A. (2010b), "Wojsko nadal pomaga powodzianom", available at: http://www. iwspsz.wp.mil.pl/pl/72_975.html (accessed 13 July 2015).

Włudyka, S., Bartnicki, A., Kruk, A. (2010), "Zabezpieczenie logistyczne sytuacji kryzysowych przez pododdziały Sił Zbrojnych RP”, Logistyka, No. 4, pp. 198-202.

Wróbel, T. (2015), "Misje poza limitem”, Polska Zbrojna, 2015, No. 7 (831), pp. 48-50.

Yin, R. K. (2010), "Designing Case Studies”, in: Frenz, M., Nielsen, K., Walters, G. (Eds.), Research Methods in Management, SAGE, London, pp. 185-226.

\section{Legal acts}

The Constitution of the Republic of Poland (1997), Konstytucja Rzeczypospolitej Polskiej z dnia 2 kwietnia 1997 r., Journal of Law 1997, No. 78, Item 483. English version available at http://www.sejm.gov.pl/prawo/konst/angielski/kon1.htm (accessed 14 May 2016).

The Act on National Defence Duties (1967), Ustawa z dnia 21 listopada 1967 r. o powszechnym obowiazku obrony Rzeczypospolitej Polskiej, consolidated text, Journal of Law 2015, No. 0, Item 144.

The Act on the State of Natural Disaster (2002), Ustawa z dnia 18 kwietnia 2002 r. o stanie kleski zywiołowej, consolidated text, Journal of Law 2014, No. 0, Item 333.

The Act on Crisis Management (2007), Ustawa z dnia 26 kwietnia 2007 r. o zarzadzaniu kryzysowym, consolidated text, Journal of Law 2013, No. 0, Item 1166. English version available at: http://rcb.gov.pl/wp-content/uploads/WERYF_-ACT_Crisis_Management_English-1.pdf (accessed 14 May 2016).

The Regulation of the Council of Ministers on the Use of Polish Armed Forces in Disaster Relief Operations (2003), Rozporządzenie Rady Ministrów z dnia 10 lutego $2003 \mathrm{r}$. w sprawie szczegółowych zasad udziału pododdziałów i oddziałów Sił Zbrojnych Rzeczypospolitej Polskiej w zapobieganiu skutkom klęski żywiołowej lub ich usuwaniu, Journal of Law 2003, No. 41, Item 347.

\section{Military publications}

AAP-6 (2015), The NATO Glossary of Terms and Definitions, NATO Standardization Agency, Brussels, available at: http://nso.nato.int/nso/nsdd/listpromulg.html (accessed 21 May 2016).

ADP 4-0 (2012), Sustainment, Headquarters Department of the Army, Washington 2012, available at: http://armypubs.army.mil/doctrine/DR_pubs/dr_a/pdf/adp4_0.pdf (accessed 21 May 2016). 
THE ROLE

OF THE

MILITARY

Andrzej Lis
ADRP 4-0 (2012), Sustainment, Headquarters Department of the Army, Washington, available at: http://armypubs.army.mil/doctrine/DR_pubs/dr_a/pdf/adrp4_0.pdf (accessed 21 May 2016).

JP-4.0 (2013), Joint Logistics, U.S. Joint Staff, available at: http://www.dtic.mil/doctrine/ new_pubs/jp4_0.pdf (accessed 21 May 2016).

NATO Logistics Handbook (2012), NATO Headquarters, Brussels 2012, available at: http://www.nato.int/docu/logi-en/logistics_hndbk_2012-en.pdf (accessed 21 May 2016). 